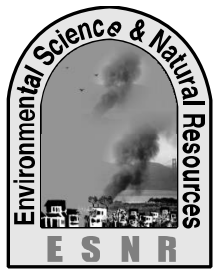

\title{
Mapping Mangrove Forest Change in Nijhum Dwip Island
}

\author{
M. M. Rahman", M. A. T. Pramanik, M. I. Islam and S. Razia \\ Forestry Division, Bangladesh Space Research and Remote Sensing Organization (SPARRSO), \\ Agargaon, Sher-E-Bangla Nagar, Dhaka-1207 \\ "Corresponding author: mahmud@sparrso.gov.bd
}

\begin{abstract}
Mangroves have been planting in the coastal belt of Bangladesh to protect the inhabitants of the coastal areas from cyclones and storm surges. Nijhum Dwip is located at the southern part of Hatiya Island. Most part of the island has been planted with the mangroves in the 1970s and 1980s; while parts of the mangroves have been deforested during the past few decades. The objectives of this research were to delineate and quantify the changes in the extent of mangroves in the island. The Landsat data of 1989, 2001, 2010 and 2018 have been utilized in the study. Three major land covers, namely forest, water and other land have been interpreted and delineated by using on-screen digitizing. The quantity of mangrove forest loss in the island is estimated as 1,024 ha, while 395 ha were afforested during 1989-2018. In the decadal change analysis, it was revealed that net forest cover change was higher in 2000s compared to other two decades and it was -425 ha. The result of the study is helpful to understand the extent and pattern of forest conversion in the island and to halt further forest loss and conserve the remaining forest.
\end{abstract}

Key words: Afforestation, Deforestation, Mangroves, Mapping, Landsat

\section{Introduction}

Bangladesh is mainly a low-lying deltaic riverine country with a high population density. The coastal areas of the country are often affected by cyclones accompanied by storm surges. In order to protect the life and properties of the coastal inhabitants from these disasters, Bangladesh Forest Department initiated mangrove afforestation in 1966 on the newly accreted land along the coastal belt of the country (Saenger and Siddiqi, 1993). The plantation program was accelerated by the World Bank aided Mangrove Afforestation Project in the 1980s. By 1990, 120,000 ha of mangroves had been planted and the afforestation program is one of the largest coastal afforestation programs in the world (Blasco and Aizpuru, 2002). Mangrove afforestation program has been continued with the various projects of Bangladesh Forest Department.

The extents of the mangroves have been changing in many places because of the conversion of forest to croplands and human settlements. In addition, mangroves have been lost by coastal erosion; forest was washed out by tidal wave or river-current. The plantation needs to be kept under continuous monitoring and reliable data on the extent of mangroves should be available periodically. Medium to high-resolution satellite images are helpful to detect and quantity the extents and the changes of forest coverage over time. Local level studies are helpful to provide new insights into the causes of deforestation (Vanonckelen and Rompaey, 2015).
Remote sensing is a powerful tool for the quantitative analysis of the extent of mangroves and mangrove forest change studies. Mangrove mapping with satellite remote sensing was summarized by Green et al. (1998), Heumann (2011) and Kuenzer et al. (2011). Global distribution of mangrove was mapped with Landsat data using hybrid supervised and unsupervised digital classification technique (Giri et al., 2011). Giri et al. (2008) mapped mangrove forest distributions and dynamics of the tsunami-affected region of Asia using time-series Landsat data. The study used hybrid supervised and unsupervised classification approach.

Giri et al. (2015) mapped the extent of mangrove in South Asia and identified the changes of mangrove forest cover from 2000 to 2012 using Landsat data. The study used Classification and Regression Tree (CART) algorithm to classify satellite image. Three case studies were conducted to identify the rates, patterns and causes of changes in Indus Delta (Pakistan), Goa (India) and Sundarbans (Bangladesh and India). Mangrove forest dynamics in the Sundarbans was studied using multi-temporal Landsat satellite data from 1973 to 2000 (Giri et al., 2007). Supervised classification technique was applied to prepare forest maps. The study revealed that the areal extent of Sundarbans has not been changed significantly (approximately 1.2\%) but the forest is continuously changing because of erosion, aggradation, deforestation and mangrove rehabilitation programs. 
A knowledge-based approach was applied to map mangroves in the Waitemata Harbor of Auckland, New Zealand from SPOT data (Gao et al., 2004). Conchedda et al. (2008) applied object-based image analysis for mapping and change analysis in the mangrove ecosystem of Low Casamance, Senegal. The study used SPOT XS data and assessed changes of mangrove forest for the period of 1986-2006. Mapping the extent and changes of mangroves has been done in the coastal belt of Bangladesh using time-series Landsat data of 1989-2010 (Rahman and Pramanik, 2015). The study prepared forest maps and assessed the changes of mangrove coverage by on-screen digitizing of digital satellite data.

There are few studies that estimated forest and LULC (Land Use and Land Cover) change in Southern Hatiya and Nijhum Dwip region. Mahmood (2017) estimated LULC changes in Southern Hatiya including Nijhum Dwip for the period of 1989-2017. The study utilized Landsat Thematic Mapper (TM) data of 1989 and 2001, and Landsat Operational Land Imager (OLI) data of 2017 to identify LULC changes in the region. Another study by Hossain et al. (2016) quantified forest cover changes in Nijhum Dwip islands for the period of 2001-2016 with Landsat TM data of 2001, 2006 and 2011, and OLI data of 2016. Those study presented LULC/forest cover maps and statistics for historical, recent and intermediate years but did not attempt to prepare LULC/forest cover change maps and statistics. One study (Rahman and Pramanik, 2015) attempted to develop change map but it assessed changes up to 2010.
The objectives of this study were to (i) prepare forest cover maps and change maps in Nijhum Dwip Region over the last thirty years (1989-2018) and (ii) made change analysis of mangrove coverage for the period of 1989-2001, 2001-2010 and 2010-2018.

\section{Materials and Methods}

\section{Study area and datasets}

Nijhum Dwip located at the southern part of Hatiya Island belongs to the central region of the coastal belt of Bangladesh (Fig. 1). Clusters of islands including Char Osman appeared in the early 1950s in the shallow estuary of the Bay of Bengal. Those islands were located in the south part of Noakhali. Char Osman was later called Nijhum Dwip. The study area also includes Char Kabira, which is located at the south-western part of Nijhum Dwip. The island was formed during 2000s. In 1974, Bangladesh Forest Department initiated mangrove afforestation in the island and the appearance of island on satellite image in early 1974 is presented in Fig. 2. Most of the island has been planted with mangroves during 1970s and 1980s. The major species of the plantation was Keora (Sonneratia apetala). Considerable amount of Gewa (Excoacera agallocha) has also been noticed in the plantation during recent field visits. Baen (Avicennia officinalis) is also seen in some parts of the plantation. Char Kabira was planted in 2010s. There were few patches of mangroves planted in the eastern and south-eastern part of the island during 2010-2018.

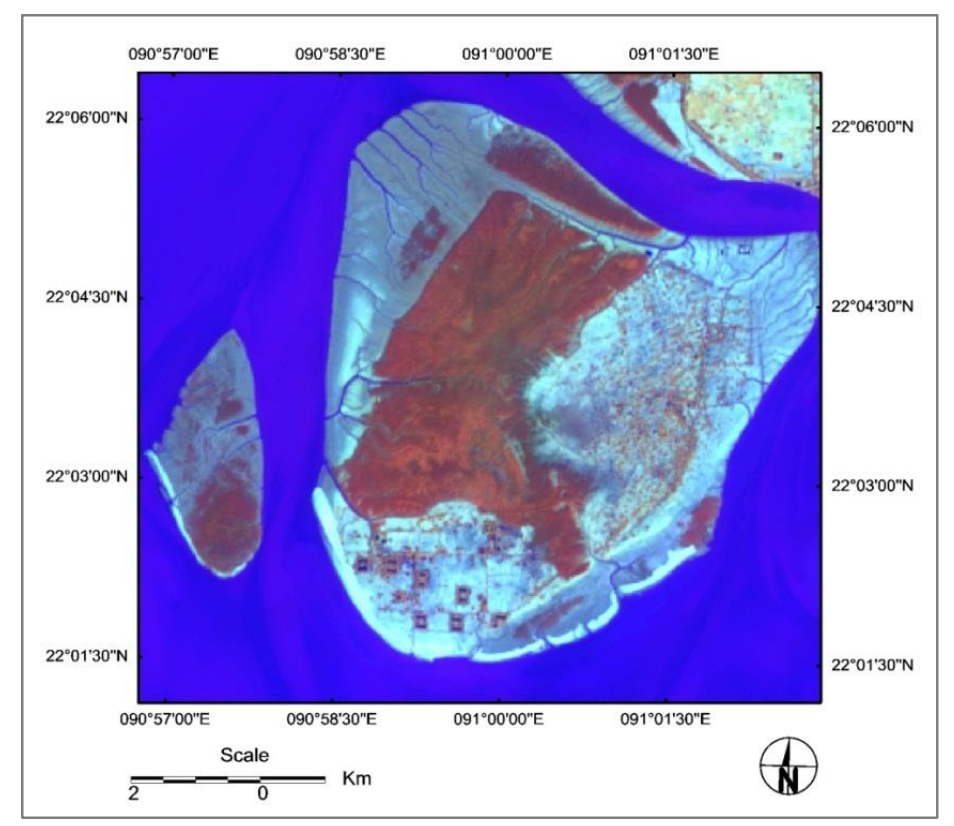

Fig. 1. Location of the study area 


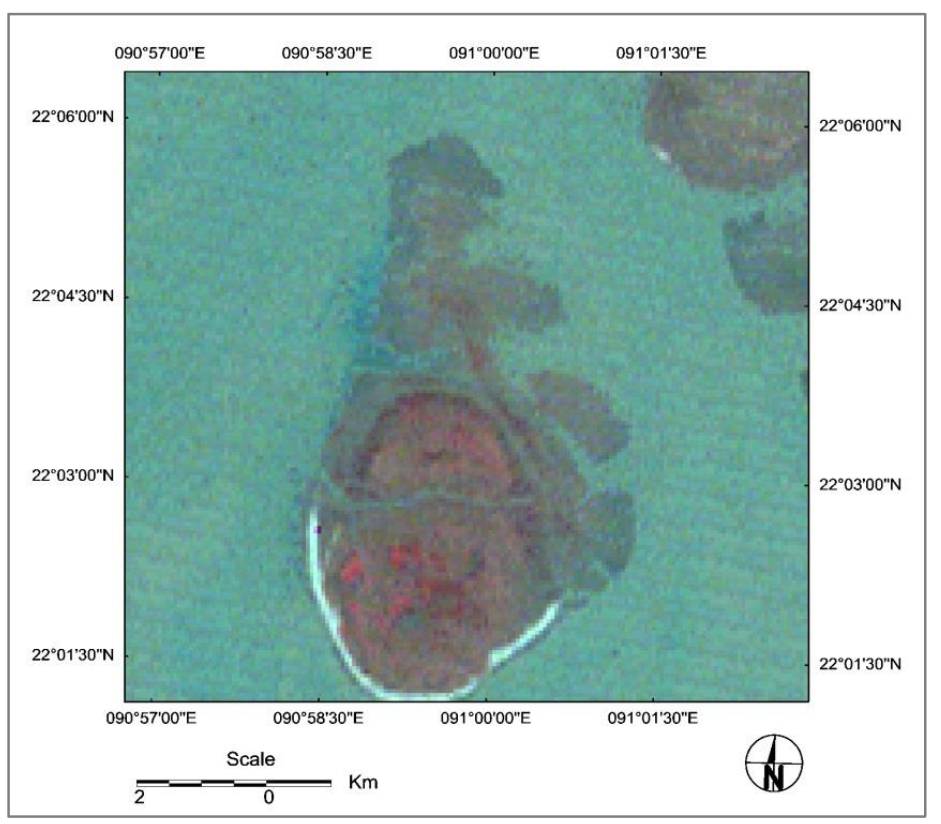

Fig. 2. The appearance of Nijhum Dwip on Landsat Multispectral Scanner (MSS) image (9 January, 1974)

Time-series Landsat satellite data was used in the study. The datasets are from Landsat Thematic Mapper (TM) of 1989 and 2010, Landsat Enhanced Thematic Mapper Plus (ETM+) of 2001 and Landsat Operational Land Imager (OLI) image of 2018 (further details in
Table 1). Field visits were conducted during 20172018 to check the geometric accuracy of Landsat satellite image, the interpretation of major land covers (forest, water and other land) and the status and distribution of mangroves in the island.

Table 1. Description of Landsat satellite data

\begin{tabular}{|l|l|l|l|}
\hline Sl No. & Satellite & Sensor & Acquisition date \\
\hline 1 & Landsat 5 & Thematic Mapper (TM) & 5 January, 1989 \\
\hline 2 & Landsat 7 & Enhanced Thematic Mapper Plus (ETM+) & 7 February, 2001 \\
\hline 3 & Landsat 5 & Thematic Mapper (TM) & 8 February, 2010 \\
\hline 4 & Landsat 8 & Operational Land Imager (OLI) & 29 January, 2018 \\
\hline
\end{tabular}

\section{Methodology}

\section{Landsat image pre-processing}

Level 1 terrain corrected Landsat data was downloaded from United States Geological Survey website. Compressed data was uncompressed to individual bands. Bands were layer stacked to generate multispectral image. Geometric accuracy of Landsat image was checked on the ground with portable GPS (Garmin GPS 78s). Identifiable objects like road crossing, corner of ponds etc. were identified on satellite image and on the ground. Ground coordinate obtained from GPS was compared with satellite image coordinate and found that geometric accuracy was adequate for further processing.

\section{Generation of vector layers by on-screen digitizing}

Landsat satellite images were visualized on computer screen. Different band combinations were checked and finally bands 4, 5 and 3 for Landsat 5 Thematic Mapper (TM) and Landsat 7 Enhanced Thematic Mapper Plus (ETM+); bands 5, 6 and 4 for Landsat 8 Operational Land Imager (OLI) were selected for visualizing in red, green and blue (rgb) color composite as optimal band combination for forest cover mapping. Other combinations like 5, 4 and 3 for Landsat $5 / 7$ and 6,5 and 4 for Landsat 8 were also helpful for the separation of bare land from other vegetation. Bare land was appeared as pink in this band combination. 
Interpretation was started from the historical image. Mangroves in the island appeared on 1989 Landsat image was visualized on computer-screen and digitized. After the completion of digitizing the mangrove layer of 1989, the layer was overlaid to 2001 satellite image. The change in the extent of forest coverage was detected and added keeping the earlier forest boundaries of 1989. After completion, the vector coverage was saved as 1989-2001 change layer. Approximately two Landsat pixels were considered as minimum mapping unit during the generation of vector layer; it means that if forest change is noticed approximately for the extent of two Landsat pixels, approximately 0.18 ha, was digitized. All polygons were interpreted both for 1989 and 2001 and stored in two columns. Areas of each polygon was computed and summarized to assess forest cover change over the period of 1989-2001. Similarly, change map was generated and change statistics was computed for 2001-2010 and 2010-2018.
After the completion of above time series change maps of 1989-2001, 2001-2010 and 2010-2018, forest maps of Nijhum were extracted for 1989, 2001, 2010 and 2018. After unifying the forest cover maps of 1989 and 2018, forest cover change map of 1989-2018 was generated. This change map was overlaid to both 1989 and 2018 satellite image to check any error, sliver polygon and corrected, if necessary. From this change map, forest cover change statistics was generated for the period of 1989-2018.

\section{Results and Discussion}

\section{Forest cover mapping during 1989-2018}

Most of the Nijhum Dwip was planted with mangrove and it is visible on 1989 satellite image (Fig. 3). Mangrove was deforested in the eastern part of the island over the last few decades. The total mangrove forest area in Nijhum Dwip region was found 2,461 ha in 1989, which was reduced to 2,294 ha in 2001. Again it was reduced to 1,869 ha in 2010 and finally to 1,831 ha in 2018 (Table 2). The gradual changes in forest cover is mapped and presented in Fig. 4.

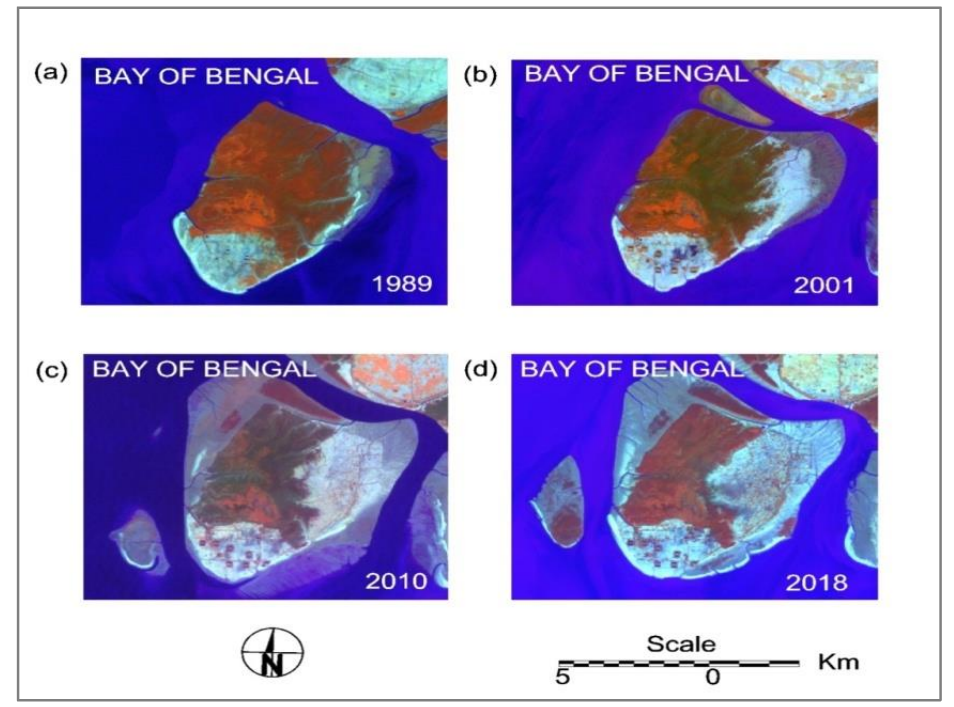

Fig. 3. Landsat satellite images of (a) 1989, (b) 2001, (c) 2010 and (d) 2018. Landsat Thematic Mapper/Enhanced Thematic Mapper Plus (TM/ETM+) bands of 5, 4 and 3 and Landsat-8 Operational Land Imager (OLI) bands of 6, 5 and 4 have been assigned in red, green and blue (rgb). Forest is appeared in dark brown.

Table 2. The extent of mangrove plantation in Nijhum Dwip over the last few decades

\begin{tabular}{|c|c|c|}
\hline S1. no. & Year & Area (ha) \\
\hline 1 & 1989 & 2,461 \\
\hline 2 & 2001 & 2,294 \\
\hline 3 & 2010 & 1,869 \\
\hline 4 & 2018 & 1,831 \\
\hline
\end{tabular}




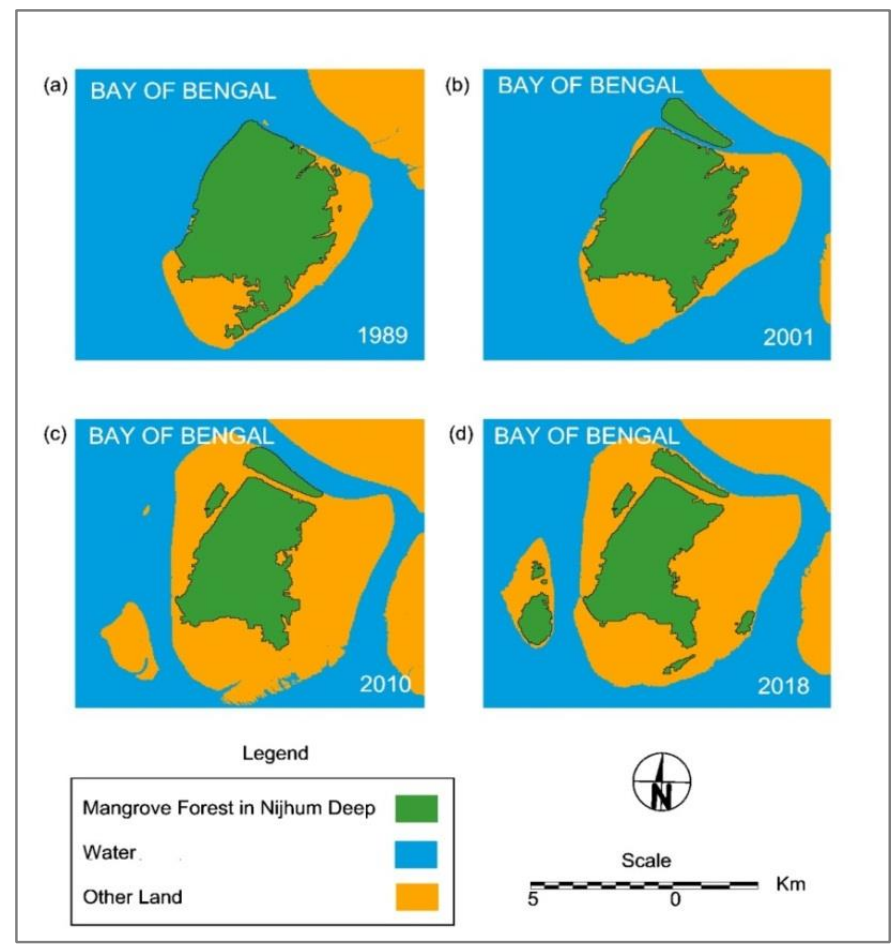

Fig. 4. Mangrove forest coverage in Nijhum Dwip region over the last few decades: (a) 1989 (b) 2001 (c) 2010 and (d) 2018

\section{Forest cover change assessment for 1989-2018}

Forest cover change was assessed for 1989-2018 by computing change matrix (Table 3). Change matrix represents not only the total net change but also the dimension of change of representing conversion of individual classes considered in the analysis. The last column of the matrix represents the total area of individual classes for the time of origin (historical time) and bottom row represents the total area of destination (recent time). Diagonal cells (shaded cells) in the matrix represent the area of stable class. The upper right portion of diagonal cells (shaded cells) represents deforestation (forest converted to water or other land). The lower left portion of the diagonal shaded cells represents afforestation, water converted to land (tidal mudflat) and finally to forest.

Table 3. Forest cover change matrix 1989-2018

\begin{tabular}{|l|r|r|r|r|}
\hline & Forest & Water & Other land & Total (1989) \\
\hline Forest & 1,437 & 8 & 1,016 & 2,461 \\
\hline Water & 384 & - & - & 384 \\
\hline Other land & 11 & - & - & 11 \\
\hline Total (2018) & 1,831 & 8 & 1,016 & 2,855 \\
\hline
\end{tabular}

N. B. Total sum might be slightly different because of summing of digits after decimals

The total area of forest change during the period has been represented in different categories; i.e., stable forest, deforestation and afforestation. Deforestation took place by two processes; forest to other land and forest to water. Forest is converted to other land by human intervention, while forest is converted to water by natural process such as coastal erosion. There are two types of conversion in afforestation process: other land to forest and water to forest. Land conversion from water to forest means newly accreted land was formed in the sea, which was later planted with the mangroves or satellite image was acquired during high tide condition, which leads to hide the newly accreted mudflats by the tide-water.

Forest was primarily cleared in the island by the human activity; 1,016 ha of forest were converted to cropland and settlements. The major part of such conversion is located at the eastern part of the plantation though smaller-scale deforestation is noticed in the southern part of mangrove-fringe in the island (Fig. 5). A narrow strip of mangrove was lost in the northern and north-western part of mangrove patches, 
which was primarily lost by coastal erosion in the 1990s. About 8 ha of forest were lost by coastal erosion during the study period. Later in 2010s, accretion trend is noticed surrounding the island. The total area of afforestation was 395 ha. The major conversion was water to forest, which was 384 ha; forest was raised to the newly accreted land that was under water on 1989 satellite image.

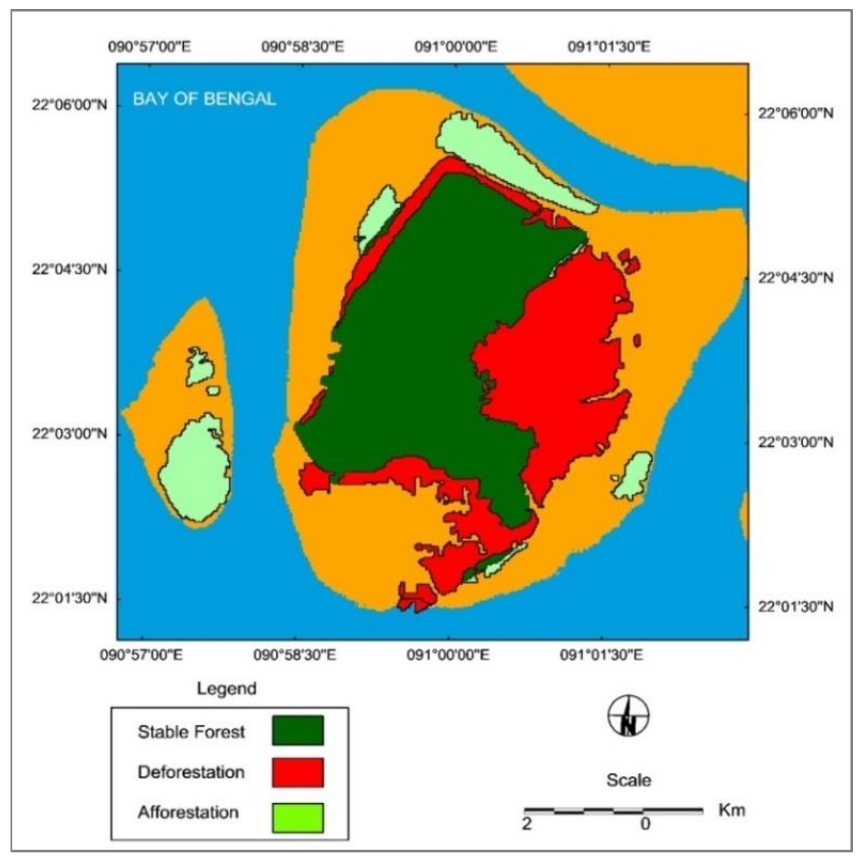

Fig. 5. Forest cover changes in Nijhum Dwip during 1989-2010

Forest cover estimated from current study is comparable with other studies. Current study estimated mangrove forest cover of Nijhum Dwip 2,294 ha in 2001, while Hossain et al. (2016) reported forest cover 2,332 ha at the same year. Forest cover was estimated as 1,869 ha for 2010 from the current study and Hossain et al. (2016) reported mangrove forest cover was 1,865 ha in Nijhum Dwip in 2011

\section{Decadal forest cover change analysis}

An overview result representing decadal forest cover changes for the period of investigation is presented in Table 4. Total deforestation was highest during 20012010 that was 499 ha. The deforestation was lower in other two decades; 347 ha in 1989-2001 and 261 ha in 2010-2018. On the other hand, the total area of afforestation was highest in 2010s and it was 223 ha. The lowest amount of afforestation was noticed during 2001-2010 that was 75 ha. Net change in forest area is the difference of afforested and deforested area. Negative sign indicates deforestation. Net change rate in forest area was computed by dividing the total net change in forest area by the time span (number of years). Similarly, highest rate of net change in forest area was noticed for 2001-2010 (-47 ha per year) and the lowest rate of net change in forest area was computed for 2010-2018 (-5 ha per year).

Table 4. Total and periodic changes of mangrove plantation in Nijhum Dwip during 1989-2018

\begin{tabular}{|c|c|c|c|c|c|c|}
\hline $\begin{array}{c}\text { Change } \\
\text { interval }\end{array}$ & $\begin{array}{c}\text { Period of } \\
\text { change }\end{array}$ & $\begin{array}{c}\text { Total } \\
\text { afforestation }\end{array}$ & $\begin{array}{c}\text { Total } \\
\text { deforestation }\end{array}$ & $\begin{array}{c}\text { Net change of } \\
\text { forest area (ha)* }\end{array}$ & $\begin{array}{c}\text { Time span } \\
\text { of change } \\
\text { (years) }\end{array}$ & $\begin{array}{c}\text { Net change } \\
\text { rate of } \\
\text { forest } \\
\text { area } \\
\text { (ha/year)* }\end{array}$ \\
\hline \multirow{2}{*}{$\begin{array}{c}\text { Decadal } \\
\text { interval }\end{array}$} & $1989-2001$ & 180 & 347 & -167 & 12 & -14 \\
\cline { 2 - 8 } & $2001-2010$ & 75 & 499 & -425 & 9 & -47 \\
\cline { 2 - 8 } & $2010-2018$ & 223 & 261 & -38 & 8 & -5 \\
\hline Total & $1989-2018$ & 395 & 1,024 & -630 & 29 & -22 \\
\hline
\end{tabular}

N. B. Total sum might be slightly different because of summing of digits after decimals. *Negative sign in forest change statistics means deforestation 
Forest cover change was presented in the change matrices for the decadal time intervals starting from 1989 to 2018 (Table 5-7, Fig. 6). The unchanged forest area was 2,114, 1,795 and 1,608 ha for the period of
1989-2001, 2001-2010 and 2010-2018, respectively. Total area of deforestation was 347, 499 and 261 ha for the above three decadal time period, respectively.

Table 5. Forest cover change matrix 1989-2001

\begin{tabular}{|l|r|r|r|r|}
\hline & Forest & Water & Other land & Total (1989) \\
\hline Forest & 2,114 & 97 & 250 & 2,461 \\
\hline Water & 177 & - & - & 177 \\
\hline Other land & 3 & - & - & 3 \\
\hline Total (2018) & 2,294 & 97 & 250 & 2,641 \\
\hline
\end{tabular}

N. B. Total sum might be slightly different because of summing of digits after decimals

Table 6. Forest cover change matrix 2001-2010

\begin{tabular}{|l|r|r|r|r|}
\hline & Forest & Water & Other land & Total (1989) \\
\hline Forest & 1,795 & 28 & 471 & 2,294 \\
\hline Water & 69 & - & - & 69 \\
\hline Other land & 6 & - & - & 6 \\
\hline Total (2018) & 1,869 & 28 & 471 & 2,368 \\
\hline
\end{tabular}

N. B. Total sum might be slightly different because of summing of digits after decimals

Table 7. Forest cover change matrix 2010-2018

\begin{tabular}{|l|r|r|r|r|}
\hline & Forest & Water & Other land & Total (1989) \\
\hline Forest & 1,608 & 17 & 244 & 1,869 \\
\hline Water & 53 & - & - & 53 \\
\hline Other land & 170 & - & - & 170 \\
\hline Total (2018) & 1,831 & 17 & 244 & 2,092 \\
\hline
\end{tabular}

N. B. Total sum might be slightly different because of summing of digits after decimals

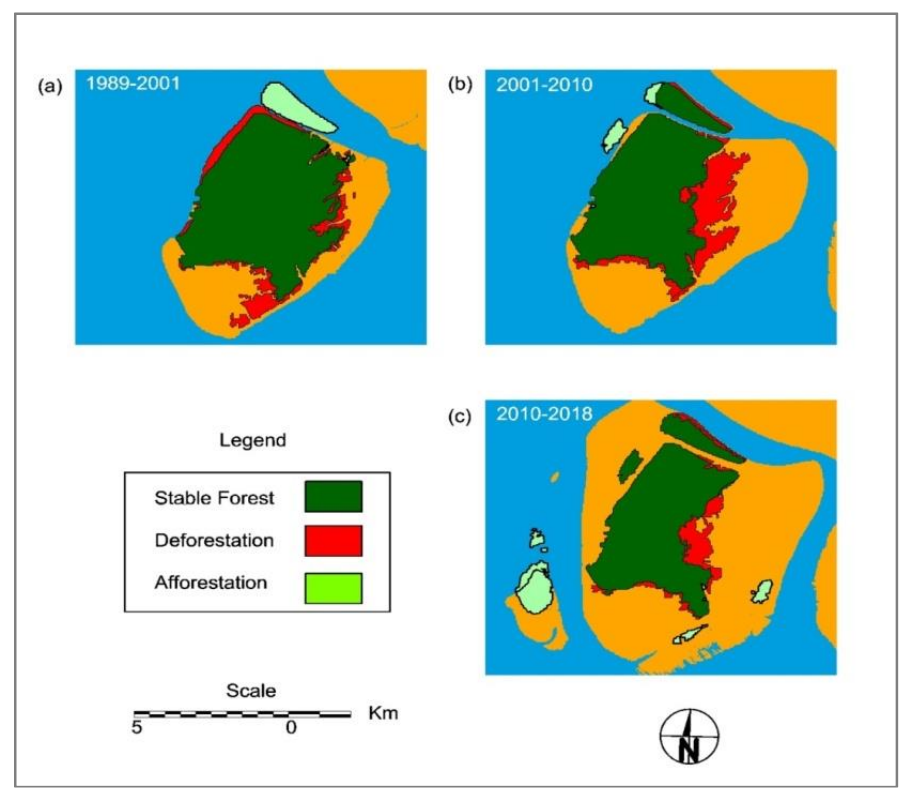

Fig. 6. Time-series changes of mangrove forest cover in Nijhum Dwip for the period of (a) 1989-2001 (b) 2001-2010 and (c) 2010-2018. Background images are the classified satellite images of the historical years, such as 1989, 2001 and 2010 for the figures a, b and c, respectively 
Forest cover in the island has been changing primarily because of the conversion of forestland to cropland and settlements. The landless migrants from the other parts of the country (including the people who lost their land by river or sea erosion) have been settled down in the island. The migrants have been clearing and converting forestland to cropland and settlements. Furthermore to this investigation, local-level studies should be concentrated to understand the deep insight of the human dimension of deforestation and explore the causal factors and deforestation processes in the island. Apart from the anthropogenic reasons of deforestation, part of the mangrove plantation has been lost by natural factors, i.e. coastal erosion, particularly in the north-western part of the plantation patch during 19892001 and northern part of plantation during 2001-2010 and 2010-2018.

\section{Conclusions}

Forest cover change in Nijhum Dwip region has been assessed for 1989-2018 based on forest cover mapping and change analysis. The total area of mangrove forest loss for the period of 1989-2018 was 1,024 ha. In this period, 395 ha of mangroves have been planted. The net loss of forest area was highest in 2001-2010 (change rate -47 ha per year) and lowest in 2010-2018 (change rate -5 ha per year). Forest loss is concentrated in the eastern and north-eastern part of the island. There was some forest loss in the western and northern part of the island by coastal erosion; forest was lost by tidal wave. Forest conversion primarily took place for agricultural and settlement purpose by the migrants from other regions. The result of the study will be helpful to understand the rate and pattern of forest conversion in the island for forest managers and policy makers to halt further deforestation and conserve the remaining forest.

There were some limitations of the study. The study utilized visual interpretation and on-screen digitizing technique, which is time consuming. Landsat data was used for mapping the changes of forest cover and analyzing the decadal changes of forests in the study area. Landsat image has the spatial resolution of $30 \mathrm{~m} \times 30 \mathrm{~m}$. The minimum mapping unit of change analysis was equivalent to two Landsat pixels. Forest conversion at a finer scale may not be represented by this dataset.

Further research should be concentrated to develop automatic image processing technique like advanced digital classification and image segmentation approach for forest cover change mapping and assessment. Although using digital classification like supervised and unsupervised classification may not accurately represent forest fragmentation, object based image analysis would be helpful for representing landscape fragmentation. Further studies should be concentrated to understand the causal factors of deforestation and develop strategy to halt forest conversion in the island.

\section{Acknowledgments}

The authors would like to acknowledge United States Geological Survey (USGS) for making Landsat data available free of charge. The Chairman of Bangladesh Space Research and Remote Sensing Organization (SPARRSO), Mr. Ziaul Hasan, is acknowledged for granting permission to publish the research work.

\section{References}

Blasco, F. and Aizpuru, M. 2002. Mangroves along the coastal stretch of the Bay of Bengal: Present status. Indian Journal of Marine Sciences, 31: 9-20.

Conchedda, G.; Durieux, L. and Mayaux, P. 2008. An object-based method for mapping and change analysis in mangrove ecosystems. ISPRS Journal of Photogrammetry and Remote Sensing, 63: 578-589.

Gao, J.; Chen, H.; Zhang, Y. and Zha, Y. 2004. Knowledge-based approaches to accurate mapping of mangroves from satellite data. Photogrammetric Engineering \& Remote Sensing, 70: 1241-1248.

Giri, C.; Long, J.; Abbas, S; Murali, R.M. and Qamer, F.M. 2015. Distribution and dynamics of mangrove forests of South Asia. Journal of Environmental Management, 148:101-111.

Giri, C.,; Ochieng, E.; Tieszen, L.L.; Zhu, Z.; Singh, A.; Loveland, T.; Masek, J. and Duke, N. 2011. Status and distribution of mangrove forests of the world using earth observation satellite data. Global Ecology and Biogeography, 20: 154-159.

Giri, C.; Pengra, B., Zhu, Z.; Singh, A. and Tieszen, A. 2007. Monitoring mangrove forest dynamics of the Sundarbans in Bangladesh and India using multi-temporal satellite data from 1973 to 2000. Estuarine Coastal and Shelf Science, 73: 91-100.

Giri, C.; Zhu, Z.; Tieszen, L.L; Singh, A.; Gillette, S. and Kelmelis, J.A. 2008. Mangrove forest distributions and dynamics (1975-2005) of the tsunami-affected region of Asia. Journal of Biogeography, 35: 519-528.

Green, E.P.; Clark, C.D.; Mumby, P.J., Edwards, A.J. and Ellis, A.C. 1998. Remote sensing techniques for mangrove mapping. International Journal of Remote Sensing, 19: 935-956. 
Heumann, B.W. 2011. Satellite remote sensing of mangrove forests: Recent advances and future opportunities. Progress in Physical Geography 35: 87-108.

Hossain, K.T.; Tanim, I. A. and Salauddin, M. 2016. Change detection of forest cover: A study Dwip National Park Hatiya, Noakhali. Jagannath University Journal of Life and Earth Sciences, 2 (1\&2): 84-90.

Kuenzer, C.; Bluemel, A; Gebhardt, S; Quoc, T.V. and Dech, S. 2011. Remote sensing of mangrove ecosystems: A review. Remote Sensing, 3: 878-928.

Mahmood, R. 2017. Monitoring LULC dynamics using geospatial techniques: A case study of coastal Hatiya Island of Bangladesh. Jagannath University Journal of Life and Earth Sciences, 3 (1\&2): 66-74.
Rahman, M.M. and Pramanik, M.A.T. 2015. Monitoring mangrove plantation along the coastal belts of Bangladesh (1989-2010), Journal of Forest and Environmental Science, 31(3): 225-234.

Saenger, P. and Siddiqi, N.A. 1993. Land from the sea: The mangrove afforestation program of Bangladesh. Ocean \& Coastal Management, 20: 23-39.

Vanonckelen, S. and Rompaey, A.V. 2015. Spatiotemporal analysis of the controlling factors of forest cover change in the Romanian Carpathian Mountains. Mountain Research and Development, 35(4): 338-350. 